\title{
Research on the Training Mode of Innovation and Entrepreneur Talents in Economics and Management Major of Applied Undergraduate Universities
}

\author{
$\mathrm{Na} \mathrm{Wu}$ \\ School of Business \\ Wuhan Huaxia University of Technology \\ Wuhan, P.R.China, 430223 \\ E-mail: haha0629@126.com
}

\begin{abstract}
The current state of innovative training talents is serious. The ministry of education clearly pointed out that colleges and universities should promote entrepreneurship and innovation education as a comprehensive reform, including the innovation and entrepreneurship education. Based on the above understanding, the students of economics and management major in applied undergraduate universities were taken as the research object, and the training mode of entrepreneurship and innovation talents in applied undergraduate universities was discussed.
\end{abstract}

Keywords-Applied undergraduate universities; Economics and management major; Entrepreneurship and innovation; Talent training mode

\section{INTRODUCTION}

A symposium on pilot work of entrepreneurship education in ordinary colleges and universities was held by the Ministry of Education in 2002, and Chinese universities gradually began to explore entrepreneurship and innovation education. With knowledge of business management, the students in economics and management major have more advantages in entrepreneurship than other students. Through the construction of innovative entrepreneurial talent training model, the quality of students can be improved quickly and effectively. When graduate, students can find corresponding jobs, and can also seek better opportunities for self-development and self-employment. However, the applied undergraduate universities started late, and the overall teaching management and talent training model are relatively imperfect ${ }^{[1]}$. How to change the traditional talent training mode, improve the quality of talents training in applied undergraduate universities, and strengthen the cultivation of innovative and entrepreneurial talents has become an important problem that needs to be solved.

\section{THE CHARACTERISTICS OF STUDENTS IN ECONOMICS AND MANAGEMENT MAJOR}

The purpose of higher education is not just employment. It also has many levels of requirements for the development of personality, the transfer of knowledge, and the formation of capabilities. The cultivation of entrepreneurship and innovation ability is helpful to the continuous improvement of universities students 'own quality level, which can realize the purpose of higher education. The major of economics and management is a comprehensive subject of arts and sciences infiltration. Compared with students of pure science, engineering, literature and history, students in economics and management major have certain characteristics in terms of thinking style, learning method or innovative practice:

(1) From the perspective of thinking mode, science students have strong logical thinking ability; however, liberal arts students are biased towards perceptual thinking. The students of economics and management major combine the characteristics of the above two, with strict logical thinking and the ability to spread and extend. Therefore, the students in the economics and management major will be more careful and thorough when face to the problems, they have unique insights, and good potential for entrepreneurship and innovation.

(2) From the perspective of knowledge, the study in economics and management subjects emphasizes the combination of theory and practice, requiring students to pay attention to economic dynamics in real time, and apply what they have learned.

(3) From the perspective of the elements of entrepreneurship and innovation, the professional courses and practical links learned by students in economics and management major are related to enterprise management, which is more conducive to the germination of entrepreneurship and innovation awareness and the development of entrepreneurship and innovation practice activities. 


\section{THE TRAINING MODEL OF ENTREPRENEURSHIP AND INNOVATION IN ECONOMICS AND MANAGEMENT MAJOR OF APPLIED UNDERGRADUATE UNIVERSITIES}

\section{A. Constructing a "Four-in-One" Full Penetration Model of} Entrepreneurship and innovation Training

The research establishes a "four-in-one" full penetration model of entrepreneurship and innovation training system based on the target system of entrepreneurship and innovation training, the curriculum system of entrepreneurship and innovation training, the practice platform system of entrepreneurship and innovation training, and the resource system of entrepreneurship and innovation training. As shown in Fig. 1. The external policy and the public opinion environment have positive influence on the training of innovative entrepreneurship talents, and the guarantee mechanism effectively promotes the implementation and operation of the talent training model.

B. Implementing the "Four-in-One" Full Penetration Model of Entrepreneurship and innovation Training

1) Target System of Innovative and Entrepreneurial Talents Training
It aims to cultivate the students with all-round development of moral, intellectual, physical and aesthetic development, has a strong sense of entrepreneurship, dares to take risks, perseverance, perseverance, solid style, entrepreneurial quality, solid entrepreneurial knowledge and basic skills, and the discovery of entrepreneurial projects ${ }^{[2]}$. And also aims to cultivate the high-quality applied innovation and entrepreneurial talents with core capabilities in development, entrepreneurship project financing and financing, operation and management of entrepreneurial projects.

2) Curriculum System of Innovative and Entrepreneurial Talents Training

At present, the mode of entrepreneurship and innovation education in applied-oriented undergraduate universities is limited to the form of "theory and simulation". Such a teaching system pays attention to the theory and neglects the practice. Most students' entrepreneurial awareness is not stimulated, but passively accepts entrepreneurial education. Therefore, if universities want to fundamentally improve the status quo, they must change the teaching system of entrepreneurship and innovation education. A "Consciousness - Theory Simulation-Practice" advanced curriculum system was created in this research.

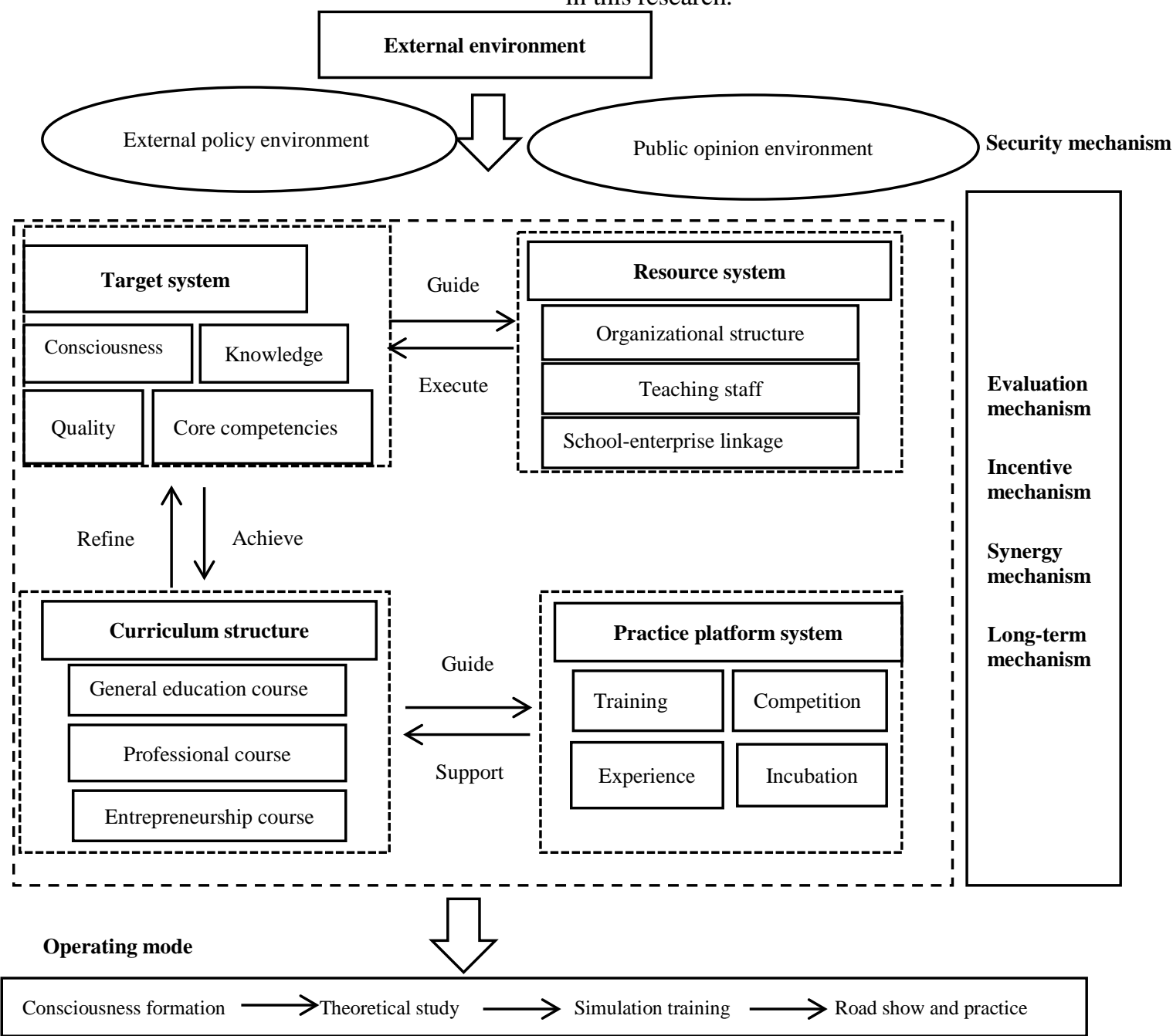

Fig. 1. The Framework of the Training Mode of Entrepreneurship and innovation in Economics and Management Major in Applied Undergraduate Universities 


\section{3) First Stage: Awareness and Theoretical Training}

In the first two years of college, students use theory to connect with practice and case analysis to understand and learn the theory of entrepreneurship and innovation, and cultivate awareness of entrepreneurship and innovation. Students learn from the case of successful entrepreneurship or failure to start a business, from the actual case to understand that entrepreneurship needs to face success and failure, and also learn how to succeed in starting a business and how to analyze the reasons for failure even if the venture fails. Only by allowing students to experience the diverse spirit of innovation and the reality of entrepreneurship and innovation, they can inspire their own entrepreneurship and innovation.

\section{4) Second Stage: Simulation Training}

Economics and management majors of applied undergraduate universities have unique advantages. Through the study of this professional course, they have a certain understanding of the knowledge of strategy, marketing planning, market analysis, human resources management, and financial analysis in enterprise management ${ }^{[3]}$. There are certain advantages in participating in the Challenge Cup Entrepreneurship Competition: the Internet + Innovation Entrepreneurship Competition, and the E-Commerce "Innovation, Creative and Entrepreneurship" Competition. These competitions help students with innovative entrepreneurial ideas to further realize their entrepreneurship.

5) Third Stage: Road show and Practice

Students master a certain theory of entrepreneurship and innovation, establish the correct values of entrepreneurship and innovation and experience the simulation exercises, and rise to the actual period of entrepreneurship and innovation roadshow. At this stage, students can not only get real guns, but also deepen theoretical knowledge in the process of experiencing practice.

\section{Practice Platform System of Innovative and Entrepreneurial Talents Training}

Practice is the most important link in entrepreneurship and innovation education. Applied undergraduate universities should fully use the existing professional practice conditions to establish a complete set of "production, learning, research" joint education system, and even through the external institutions. Conduct joint, internship and practical education, and fully expand the students' off-campus practice base, in order to build an innovative entrepreneurial practice platform system of "entrepreneurship and innovation and teaching mutual promotion, project and curriculum integration, tutor and student interaction" $"[4]$

\section{Resource system of Innovative and Entrepreneurial Talents Training}

Applied undergraduate universities have certain entrepreneurial education resources. They should pool them with social resources, establish a system of entrepreneurial education resources, make full use of various scattered and idle resources, and improve the efficiency of the use of resources. Only in this way they can avoid the waste and inefficient use of entrepreneurial resources, optimize the structure of entrepreneurial education resources, and bring into play the synergy of entrepreneurial education. Applied undergraduate universities should focus on selecting entrepreneurship mentors on the basis of merit, strengthen entrepreneurship knowledge and practical training for key teachers, and build a team of teachers for dual-teacher entrepreneurship education. Through the establishment of resources cooperation and sharing mechanism, so as to realize resource sharing, enrich entrepreneurship education.

\section{SECURITY MECHANISM OF ENTREPRENEURSHIP AND INNOVATION TALENTS IN ECONOMICS AND MANAGEMENT MAJOR OF APPLIED UNDERGRADUATE UNIVERSITIES}

Only through the study of evaluation mechanism, incentive mechanism, synergy mechanism and long-term mechanism, the effective operation of the training model of innovative entrepreneurship can be guaranteed.

\section{A. Evaluation Mechanism}

The cultivation of innovative and entrepreneurial talents is a very practical educational activity. If it is only assessed through the way of examination and completion, it is obviously not possible to comprehensively reflect the effect of talent cultivation [5]. Therefore, applied undergraduate universities should adopt a diversified assessment mechanism that combines theory, skills, and professionalism, and combines diagnostic assessment, final assessment, and process assessment.

\section{B. Incentive Mechanism}

Set up a support fund for entrepreneurship students independently. It does not account for the proportion of shares in the enterprises established by students, but only requires students to return the amount of funds after a certain period of time. This kind of application for venture capital without paying interest can trigger the gratitude of entrepreneurs. The incentive effect of this fund is far greater than the value of its capital itself.

\section{Synergy Mechanism}

At the government level, it is necessary to establish an evaluation mechanism that aims at the entrepreneurship and innovation education of applied undergraduate universities with clear objectives and rewards, especially for the application of undergraduate universities in entrepreneurship and innovation education. The overall society's expectation for entrepreneurship and innovation education should be free from the mentality of quick success and instant benefit, create a relaxed atmosphere of tolerance and failure, encourage those who have innovative and entrepreneurial ideas to bravely start a business and create a free atmosphere of advocating innovation $^{[6]}$. Enterprises can participate in the cultivation of innovative and entrepreneurial talents in economic and management majors of applied undergraduate universities to realize the role transformation, from traditional employing units to joint training units, jointly formulate training objectives, jointly build curriculum system and teaching content, jointly implement the training process, and jointly evaluate the quality of training. 


\section{Long-term Mechanism}

In order to insure the general operation and sustainability of all aspects of innovative and entrepreneurship training in economics and management major of applied undergraduate universities, it is necessary for all sectors of society to cooperate with each other highly and consistently, and for the government to take the lead and issue positive policies to ensure the implementation of the policies. Meanwhile, students, University teachers, social forces and students' parents need to participate together.

\section{SUMMARY}

Cultivating innovative and entrepreneurial talents is the main way of higher education reform in China, and also a powerful measure to improve the quality of education. Constructing a "four-in-one" full penetration model of entrepreneurship and innovation training is a new education mode for economic and management major in applied undergraduate universities. It is the main way to train applied economics and management major to meet the current social needs. Based on this study, we hope to have some guidance and reference for the practice of entrepreneurship and innovation training of economics and management major in applied undergraduate universities.

\section{ACKNOWLEDGEMENT}

This paper was supported by research topics of provincial teaching in higher institutions of Hubei Province (Grant NO. 2016468).

\section{REFERENCES}

[1] Doan winkle, Jeff Vanevenhoven, The structure and scope of entrepreneurship program in higher education about the world [J]. Journal of EntrepreneurshipEducation, Volume 16, pp. 101-122, 2013.

[2] Peter S. Sherman et al. Experiential Entrepreneurship in the Classroom Effects of Teaching Methods on Entrepreneurial Career Choice Intentions. Journal of Entrepreneurship Education, Vol. 11, pp. 29-42, 2008.

[3] Solomon G T.and Fernald L.W. Trends in Small Business and Entrepreneurship Education in the United States [J]. Journal of Entreneurshipr Theory and Practice, pp. 25-40, 2013(3).

[4] Duan Haiyang. Research on Training Strategies of Innovative and Entrepreneurial Talents in Local Applied Universities [J]. Journal of Entreneurshipr Theory and Practice, pp. 221, 2018(22). (In Chinese)

[5] Liu Jiqiong, Feng shuai, Xun hongyan. Research on Practical Teaching System of E-commerce Major Based on Entrepreneurship Education [J]. Journal of Electricity Education in China, pp. 33-37, 2014(5). (In Chinese)

[6] Wu Na. Research on the Current Situation and Countermeasure of Innovative and Entrepreneurial Talents Training in Economics and Management Major in Applied Undergraduate Universities [J]. Journal of Modern Commerce and Trade Industry, pp. 56-58, 2019(8) (In Chinese) 